Jakub Wiśniewski ${ }^{1}$

Uniwersytet Mikołaja Kopernika w Toruniu

\title{
Opatrzność Boża w życiu błogosławionego Henryka Kaczorowskiego
}

Bóg, stwarzając świat i człowieka, nieustannie czuwa nad swoim dziełem. Nie jest (jak chcą deiści) bogiem odległym, który nie interesuje się tym, co dzieje się ludzkością. Jest Ojcem, który w swojej opatrzności prowadzi swoje dzieci do pełni zbawienia. Towarzyszy na każdym kroku, kocha i poszukuje tych, którzy się pogubili. Człowiek jest wezwany do dialogu, do kroczenia ścieżkami Pana - Dobrego Pasterza. Bóg ma względem każdego swój plan, a człowiek jest wezwany do ufności. Ludzkie życie jest pełne pięknych chwil, pełnych szczęścia, ale są też etapy trudne, pełne bólu, niezrozumiałego cierpienia. To wielki heroizm ufać w takich okolicznościach. II wojna światowa była „ciemną doliną” dla Kościoła, zwłaszcza w Polsce. Do 1944 roku niemal 1300 kościołów było zamkniętych dla kultu. Ponad 500 zmieniono na składy towarowe. W diecezji włocławskiej na 318 kościołów zamknięto 300, 17 natomiast zburzono. Zlikwidowano niemal wszystkie krzyże i figury przydrożne. Polskie duchowieństwo, zarówno diecezjalne, jak i zakonne, poniosło przez prześladowania potężne straty. Represjom było poddanych 6367 osób, z czego 2801 poniosło śmierć.

1 Ks. Jakub Wiśniewski - prezbiter diecezji włocławskiej. Stopień magistra uzyskał na Uniwersytecie Mikołaja Kopernika w Toruniu. Od 2016 roku jest doktorantem na Wydziale Teologicznym Uniwersytetu Papieskiego Jana Pawła II w Krakowie. 
Spośród ofiar 1932 osoby należały do duchowieństwa diecezjalnego, z czego 220 księży do diecezji włocławskiej². Do tego grona należał ks. Henryk Kaczorowski, męczennik, pełen ufności w Bożą opatrzność. W tym artykule przyjrzymy się jego osobie, życiu, środowisku, w jakim się wychowywał i żył, ale przede wszystkim ukażemy, jak od samego początku aż po męczeńską śmierć ufał Opatrzności.

\section{Dzieciństwo, młodość, twórcza praca}

Nikt nie staje się od razu wielkim intelektualistą, wielkim sportowcem ani wielkim świętym. Potrzeba przejść przez wiele cierpień i utrapień (por. Dz 14,22), gdyż one weryfikują naszą autentyczną postawę. Różne doświadczenia nas ubogacają, otwierają nasze horyzonty myślowe, zmieniają. Poprzez te doświadczenia poznajemy samych siebie. Bóg wie, jacy jesteśmy, ale często pozostajemy tajemnicą dla samych siebie, dopóki nie przyjdzie nam stawić czoła różnym trudnym sytuacjom życiowym. Poznajmy zatem historię życia naszego błogosławionego, aby potem ukazać go jako człowieka od samego początku ufającego Bogu.

\subsection{Dzieciństwo}

Henryk Zygmunt Kaczorowski, syn Andrzeja i Julii, urodził się 10 lipca 1888 roku w Bierzwiennej Długiej ${ }^{3}$ w tamtejszym kościele parafialnym został również ochrzczony 15 lipca 1888 roku. Miał siedmioro rodzeństwa. W takiej rodzinie Henio (jak mówili na niego w domu) jako najstarsze dziecko uczył się troskliwości, a także życia we wspólnocie. Dwaj najmłodsi bracia, Józef i Jan, zmarli w dzieciństwie, a przed wojną w 1937 roku Henryk stracił jeszcze jednego brata - Stefana.

2 Zob. W. Jacewicz, J. Woś, Martyrologium polskiego duchowieństwa rzymskokatolickiego pod okupacją hitlerowska w latach 1939-1945, Warszawa 1977, t. 1, s. 82-88.

3 Por. S. Librowski, Ofiary zbrodni niemieckiej spośród duchowieństwa diecezji włocławskiej 1939-1945, Włocławek 1947, s. 53. 
Ojciec w młodych latach odbywał praktykę w majątku ziemskim w Bierzwiennej i tam dostał pracę jako oficjalista ${ }^{4}$, gdzie pracował do 1889 roku. Ożenił się w 1887 roku ze wspomnianą wyżej Julią. Wspólnie przeprowadzili się do Kaznowa, a następnie do Krasek ${ }^{5}$, gdzie ojciec pracował podobnie jak w poprzednich majątkach jako oficjalista. W Kraskach Henryka - wówczas sześcioletniego - i pozostałe dzieci uczyła mama Julia. Nasz błogosławiony był bardzo pilnym uczniem i robił duże postępy, wkrótce nauczył się świetnie czytać. Rodzice nie posiadali się z radości, widząc jego niepospolite zalety: wyjątkowe posłuszeństwo, skromność, pilność w nauce i niezwykłą czułość dziecinną względem rodziców (por. Kol 3, 20). Jak wspomina brat ks. Henryka: „ojciec pokładał wielkie nadzieje w swym pierworodnym synu i przeznaczył go na służbę Bogu" (por. Syr 30, 1-13) ${ }^{6}$. Rodzice, doceniając rolę wiedzy i nauki, postanowili zadbać o wykształcenie Henryka i wysłali go do szkoły w Kłodawie ${ }^{7}$. Kiedy rodzice jeździli w odwiedziny do małego Henia, nie mogli nasłuchać się pochwał, tak bowiem był miły dla wszystkich, a zarazem czynił bardzo duże postępy w nauce (por. Łk 2, 40). Ojciec, widząc rozwój syna i chcąc go jak najlepiej wykształcić, podróżował co pewien czas do Kalisza, aby tam przyjąć posadę i móc umieścić najstarszego syna w kaliskim gimnazjum. Z pomocą św. Józefa ${ }^{8}$ udało się pomyślnie załatwić sprawę i po ukończeniu przez Henryka szkoły podstawowej cała rodzina udała się do Noskowa położonego $5 \mathrm{~km}$ od Kalisza. Warto zauważyć poświęcenie i troskę ojca - Andrzeja. Nasz błogosławiony miał w dzieciństwie bardzo dobry przykład głowy rodziny, która troszczy się o swoich najbliższych i nie szczędzi sił, aby rodzinie żyło się jak najlepiej, a dzieci mogły zdobyć jak najlepsze wykształcenie. Niełatwo było codziennie przemierzać

4 Por. S. Librowski, Ofiary zbrodni niemieckiej... dz. cyt., s. 53-59.

5 Por. S. Librowski, Ofiary zbrodni niemieckiej... dz. cyt., s. 53.

6 Archiwum Diecezji Włocławskiej [dalej: ADWł], akta pers. ks. H. Kaczorowskiego, sygn.: pers 113, odpis listu brata księdza Kaczorowskiego z dnia 20 września 1946 roku zawierający informacje o nim. Jest to odpowiedź na zapytania stawiane przez księdza Librowskiego.

7 Por. K. Rulka, Kaczorowski Henryk, w: Słownik polskich teologów katolickich, pod red. L. Grzebienia, t. 6, Warszawa 1981-, s. 14.

8 ADWł, akta pers. ks. H. Kaczorowskiego, sygn.: pers 113, odpis listu brata księdza Kaczorowskiego z dnia 20 września 1946 r. zawierający informacje o nim. Jest to odpowiedź na zapytania stawiane przez księdza Librowskiego. 
10 kilometrów do szkoły pieszo, nieraz w deszczu i błocie, nieraz w mrozie i zawiejach śnieżnych. Henryk Kaczorowski jako chłopiec był mizerny i wątły. Od pierwszego roku gimnazjum zwracał na siebie uwage profesorów, którzy sadzali go w pierwszych ławkach, aby koledzy brali przykład z jego skromnego zachowania, a jego zeszyty lśniące czystością służyły za wzór (por. Łk 2, 46-47). Do następnej klasy przechodził zawsze z nagrodą i listem pochwalnym. Dyrekcja szkoły chętnie przyznawała mu stypendia naukowe?.

Przechodząc codziennie ulicami Kalisza, przyglądał się bacznie księgarniom i z wielkim zainteresowaniem zapoznawał się z wystawionymi książkami. Codziennie przynosił do domu nową książkę kupioną za grosze otrzymane na drugie śniadanie. Czytał dużo nawet podczas jedzenia. Czasu jednak do czytania nie miał za wiele, bo oprócz codziennego gruntowego przygotowania lekcji pomagał matce w pracach domowych. W tak wielkim zatroskaniu rodziców o wykształcenie dzieci nie zabrakło troski o wychowanie religijne, dlatego miesiące marzec, maj, październik gromadziły całą rodzinę przed ołtarzykiem, gdzie wspólnie odśpiewywano pieśni i litanie, którym przewodniczył ojciec (por. Syr 3, 1-16) ${ }^{10}$.

W roku 1902 cała rodzina przeprowadziła się do Kalisza. Dzięki temu nasz błogosławiony mógł codziennie być w kościele i służyć do mszy świętej, do czego również zachęcał swoich młodszych braci. Będąc już w wyższych klasach, zauważył, że gimnazjum rosyjskie nie daje całkowitego wykształcenia, że brak w nim nauki historii Polski, że język polski, literatura są mało uwzględniane w programie szkolnym, toteż wprowadził w domu uzupełnienie tych nauk. Z całym rodzeństwem odpowiednio do wieku przerabiał ćwiczenia w języku polskim, szczególną uwagę poświęcił historii ojczyzny, a każdy z rodzeństwa musiał dokładnie znać królów Polski w chronologicznym porządku, daty większych bitew i ważniejszych wydarzeń.

Kiedy w 1905 roku Polacy bojkotowali szkołę zaborczą, nie ominęło to Kalisza, dlatego młody Henryk musiał przerwać naukę. Po ukończe-

9 Por. ADWł, akta pers. ks. H. Kaczorowskiego, sygn.: pers 113, odpis listu brata księdza Kaczorowskiego z dnia 20 września 1946 r. zawierający informacje o nim. Jest to odpowiedź na zapytania stawiane przez księdza Librowskiego.

10 Por. S. Librowski, Ofiary zbrodni niemieckiej..., dz.cyt., s. 54. 
niu 5 klas gimnazjum był na tyle wykształcony i samodzielny, że został nauczycielem we wsi Słodków koło Turku i jednocześnie własnymi środkami douczał się prywatnie do matury. Tutaj skrystalizowała się ostatecznie myśl pozostania kapłanem. Po dwóch latach pracy nauczycielskiej opuścił szkołę, udając się do Seminarium Duchownego we Włocławku.

\subsection{Młodość}

Niewiele wiemy o jego latach kleryckich, nie mamy świadectw z ocenami, które pozwoliłyby stwierdzić, jak się uczył Henryk, żadnych dokumentów z tego okresu, niewiele wiemy też o sposobie formacji seminaryjnej w latach 1908-1914. Z pomocą przychodzą nam zapisane nieliczne fragmenty. Stanisław Librowski zanotował: „Kto znał młodość rektora, kto znał kleryka Kaczorowskiego, ten widział, że wymaganie rektorskie odnośnie do alumnów pokrywały się z jego życiem studenckim. Nigdy o tym nie mówił, nie stawiał siebie za przykład, lecz kto czytał Wakacje alumna, broszurę wydaną przez ks. Kaczorowskiego w 1934 r. dla alumnów, spostrzegł na jej kartach odbicie wzorowego życia kleryka z Kalisza"11. Franciszek Korszyński w Jasnych promieniach w Dachau pisze: „takim słońcem był także w Seminarium Duchownym we Włocławku, naprzód jako alumn, a później - jako profesor i rektor” ${ }^{12}$. W innym fragmencie: „Ks. Henryk Kaczorowski w całym swoim życiu szukał tylko dobra sprawy Bożej, której chciał służyć jak najlepiej. Nie szukał siebie, nie chciał błyszczeć, imponować. Przeciwnie, roztropnie i umiejętnie ukrywał swe zalety, bo pragnął, by tylko Pan Bóg miał w jego życiu swą chwałę. Tak było w jego życiu kleryckim, duszpasterskim, profesorskim i rektorskim. [...] Ks. Henryk wiele modlił się jako kleryk i jako kapłan"13. Stanisław Librowski zamieszcza trochę obszerniejszą notę z czasów kleryckich naszego błogosławionego: „W r. 1908 wstąpił do seminarium duchownego we Włocławku. Był odtąd ledwie gościem w domu. Gdy przybywał na wakacje, wchodziły z nim do domu radość i humor, gwar i życzliwość. Tak poważny w szkole przy zdo-

11 S. Librowski, Ofiary zbrodni niemieckiej..., dz.cyt., s. 57.

12 F. Korszyński, Jasne promienie w Dachau, Poznań 1957, s. 169.

13 F. Korszyński, Jasne promienie w Dachau, dz.cyt., s. 170, 173. 
bywaniu wiedzy, w kole rodzinnym wydawał się zupełnie beztroskim. Wpadał niespodziewanie do domu, wnosząc dużo zamieszania i wesołości, rozmawiał na wszystkie tematy, dyskutował... Nie zdążyli się jeszcze nagadać z nim, nacieszyć, a już pakował walizkę i uciekał do swych obowiązków, najpierw kleryckich, a potem profesorskich. Matka nazywała go słońcem w rodzinie. Rzeczywiście promienie słońca schodziły pod dach rodziny razem z młodym alumnem. Był wzorowym klerykiem" ${ }^{14}$. Ze wspomnień jego brata wiemy, że najszczęśliwszą chwilą w jego życiu był moment, kiedy zostawszy klerykiem, przyodział po raz pierwszy sutannę. Jego radość podzielali także rodzicie ${ }^{15}$. Święcenia diakonatu przyjął Henryk 7 marca 1913 roku, tegoż samego roku został wysłany do Akademii Duchowej w Petersburgu ${ }^{16}$.

\subsection{Twórcza praca}

Święcenia prezbiteratu Henryk Kaczorowski przyjął 13 czerwca 1914 roku z rąk bp. Jana Cieplaka w kościele Wniebowzięcia Najświętszej Maryi Panny w Petersburgu. Gdy przybył do rodzinnego domu, nie mógł wrócić na studia, gdyż wybuchła I wojna światowa. Pozostał przy rodzinie i zaczął pracować jako kapelan szpitala kaliskiego, dając się poznać jako gorliwy kapłan i apostoł chorych. Po kilkunastu miesiącach pobytu w Kaliszu został wysłany do Lichenia, w 1916 roku do parafii Sadlno, a następnie tego samego roku wydelegowano go jako wikariusza do Sulmierzyc, gdzie po śmierci proboszcza pozostał tymczasowym zarządcą parafii. Od lipca do września 1920 roku, kiedy to bolszewicy atakowali Polskę, pełnił posługę kapelana wojska polskiego. W nawiązaniu do tego w 1937 roku rektor Kaczorowski otrzymał odznakę pamiątkową 14 pułku piechoty, stacjonującego we Włocławku ${ }^{17}$.

14 S. Librowski, Ofiary zbrodni niemieckiej..., dz.cyt., s. 55.

15 Por. ADWł, akta pers. Ks. H. Kaczorowskiego, syng.:pers 113, odpis listu brata księdza Kaczorowskiego z dnia 20 września 1946 r. zawierający informacje o nim. Jest to odpowiedź na zapytania stawiane przez księdza Librowskiego.

16 Zob. S. Librowski, Ofiary zbrodni niemieckiej..., dz. cyt., s. 53-59.

17 Por. ADWł, akta pers. ks. H. Kaczorowskiego, sygn.: pers 113, k. 5. 
Kiedy skończyła się wojenna zawierucha, wśród nowych studentów na dopiero co utworzonym Katolickim Uniwersytecie Lubelskim znalazł się młody ksiądz Henryk Kaczorowski, celem dokończenia studiów petersburskich ${ }^{18}$. Tak się szczęśliwie złożyło, iż w annałach dokumentujących dzieje tej uczelni ks. Kaczorowski zapisany jest jako pierwszy wypromowany doktor ${ }^{19}$, a miało to miejsce w 1922 roku. Wróciwszy do diecezji, ks. Henryk nie mógł narzekać na brak pracy: został wykładowcą teologii moralnej, katechetą włocławskich gimnazjów, a do tego odbywał liczne naukowe podróże. Przez 3 lata pełnił funkcję redaktora naczelnego „Ateneum Kapłańskiego”.

\subsection{Błogosławiony ksiądz Henryk jako rektor}

Na urząd rektora Wyższego Seminarium Duchownego we Włocławku ks. Henryk został mianowany 26 maja 1928 roku $^{20}$. Wysokie wymagania stawiane klerykom przez rektora były odbierane jako wyraz miłości do nich i do sprawy Bożej, tym bardziej że potwierdzał to na co dzień niedającym się ukryć głębokim życiem wewnętrznym i stawianymi sobie wymaganiami, zawsze większymi niż wobec innych. „Ukochał młodzież duchowną i jej poświęcił najpiękniejsze lata swojego życia. Naukowcem nie był, był wychowawcą, był ojcem. Był surowym rektorem, ale klerycy go lubili, a to dlatego, iż od siebie nie mniej wymagał niż od nich"21. Ujmował alumnów swym twardym stylem życia połączonym z wielką dobrocią, kulturą i szacunkiem w stosunku do nich. Bardzo troszczył się o biednych alumnów, którym dyskretnie na różny sposób niósł pomoc. Często przyznawał im stypendia z własnej pensji. Był to człowiek bez wymagań dla siebie. Skromny w mieszkaniu, odżywianiu i ubiorze. Miał hojną rękę dla biednych.

Warto przytoczyć świadectwo Stanisława Olejnika:

\footnotetext{
18 Por. ADWł, akta pers. ks. H. Kaczorowskiego, sygn.: pers 113, k. 2.

19 Por. ADWł, akta pers. ks. H. Kaczorowskiego, sygn.: pers 113, k. 5.

20 Por. ADWł, akta pers. Ks. H. Kaczorowskiego, sygn.: pers 113, k. 22.

21 S. Librowski, Ofiary zbrodni niemieckiej..., dz. cyt., s. 54.
} 
To wspaniały człowiek i kapłan, może najwspanialszy z tych, których Opatrzność postawiła dotąd na drodze mojego życia. [...] To po prostu mistrz w nawiązywaniu i prowadzeniu miłego i swobodnego dialogu. Ten urzekający talent, tę wielką umiejętność, wrodzoną czy nabytą, przejawiał nie tylko na lekcjach „zwyczajów towarzyskich", lecz na co dzień - na korytarzu w przerwach między wykładami, w ogrodzie podczas południowych spacerów, w czasie czwartkowych wspólnych spacerów rekreacyjnych ${ }^{22}$.

„Zajęcia rektorskie zakończył w wakacje 1939 roku. W Słowniku polskich teologów katolickich napisano, że czas rektoratu był dla niego najcięższym okresem w życiu. Dlaczego? Ano może dlatego, że zdrowie miał słabe (wszak kilkakrotnie prosił usilnie bp. Radońskiego o zwolnienie z tegoż urzędu). Świadek tamtych dni abp Kazimierz Majdański pisze, że kiedy bp Radoński zwolnił ks. Kaczorowskiego z tego urzędu, ten powtarzał za św. Pawłem: «Gaudium meum et corona mea». Mówił to ze łzami, a były to łzy radości”23. Nie wiemy, co zamierzał na przyszłość sam zainteresowany ani co zamierzała władza diecezjalna. Wszelkie plany pokrzyżował wybuch drugiej wojny światowej.

\section{Szczytowa próba wiary}

Przez wiele ucisków człowiek musi wejść do królestwa Bożego (por. Dz 14, 22). Owe „uciski”, o których mówi św. Paweł, to sprawdziany naszej wiary i wierności. One najpełniej ukazują głębię lub powierzchowność cnót w człowieku. „Uciski” mają konkretny cel, prowadzą do zbawienia, i chociaż ono jest darem, to dostąpią go ci, którzy wytrwają do końca.

\subsection{II wojna światowa}

Po złożeniu urzędu rektora w życiu księdza Henryka wcale nie nastały łatwiejsze czasy. On sam przeczuwał, co może się wkrótce wydarzyć. „Wiosna i lato 1939 r. - pełne nadziei. W nas alumnach Włocławskiego

22 S. Olejnik, Takie to były czasy, tacy to byli ludzie. Karty dziennika, Wrocław 2009, s. 44.

23 J. Szymański, Ksiądz Henryk Kaczorowski: moralista, rektor $i$ wychowawca, „Studia Włocławskie" 11 (2009), s. 436. 
Seminarium Duchownego - nadzieja ludzi młodych. Nasz czcigodny rektor, ks. Henryk Kaczorowski, ostrzegał: Niech nikt nie pragnie wojny. Wojna jest wielkim nieszczęściem" ${ }^{24}$. Okupanci rozpoczęli systematyczne likwidowanie wszystkiego, co polskie. To prześladowanie zwróciło się szczególnie przeciw Kościołowi katolickiemu, ponieważ księży uważano za duchowych i intelektualnych przywódców narodu. Jeszcze przed wkroczeniem Niemców do Włocławka zapadła decyzja, aby klerycy na czele z biskupem ordynariuszem Karolem Radońskim wraz z profesorami udali się do Lublina na KUL. Udał się tam również ks. Henryk, wierząc, że tam będzie można rozpocząć rok akademicki ${ }^{25}$. Wyjechali 6 września, po niełatwej podróży znaleźli się w Warszawie. Tam jednak pod wpływem trudnych wydarzeń i okoliczności, jakie zastali, postanowiono powrócić. Nasz błogosławiony od 11 października 1939 roku był tymczasowym administratorem parafii św. Jana we Włocławku, gdyż wielu księży było uwięzionych i parafie były nieobsadzone. W tej sprawie bp Kozal został wezwany przez gestapo 7 listopada 1939 roku w godzinach popołudniowych. Niemieccy okupanci zapewniali, że aresztowania księży były pomyłką i zostaną oni zwolnieni, aczkolwiek przechodzą teraz krótkie przeszkolenie. Natomiast seminarium miało zacząć funkcjonować nazajutrz, czyli od 8 listopada. Niestety było to kłamstwo i jeszcze tego samego dnia wszyscy zostali uwiezieni we włocławskim wiezieniu.

Z powodu choroby ks. Henryk przeniesiony został z więzienia do szpitala św. Antoniego we Włocławku ${ }^{26}$. W tym szpitalu przebywał od 13 grudnia 1939 roku do 28 marca 1940 roku, leczony na opadnięcie żołądka i chroniczne zapalenie jelita grubego ${ }^{27}$. Kiedy stan zdrowia się poprawił, został przewieziony przez żołnierzy niemieckich do salezjańskiego klasztoru w Lądzie, gdzie od 1 stycznia 1940 roku przebywali włocławscy księża i alumni wraz z bp. Kozalem ${ }^{28}$. Nie był to obóz we właściwym tego słowa

24 K. Majdański, Bądźcie moimi świadkami, Łomianki 1999, s. 27.

25 Por. A. Poniński, Kaczorowski Henryk, w: Włocławski słownik biograficzny, Włocławek 2002, s. 81 .

26 Por. S. Librowski, Ofiary zbrodni niemieckiej..., dz. cyt., s. 58.

27 Zob. Biblioteka Wyższego Seminarium Duchownego, Błogosławiony ks. Henryk Kaczorowski. Zaświadczenie lekarskie o stanie zdrowia z 17 VIII 1940.

28 Por. W. Frątczak, Biskup Michał Kozal. Życie - męczeństwo - kult, Włocławek 2009, s. 128. 
znaczeniu. Był to raczej rodzaj domowego aresztu. Uwięzieni mieli prawo do korzystania z całego klasztoru łącznie z ogrodem. Kontrole odbywały się bardzo rzadko. Księdzu Henrykowi udało się odwiedzić swoją rodzinę w styczniu 1941 roku. Jako argument do przepustki podał właśnie zły stan zdrowia ojca.

3 kwietnia 1941 roku gestapo przybyło do Lądu. Biskupowi i księżom (w tym ks. Henrykowi) rozkazano spakować rzeczy osobiste, a także popodpinać sutanny, aby przybrali wygląd osób świeckich. Po kilku godzinach jazdy przywieziono ich do obozu w Inowrocławiu ${ }^{29}$. Wkrótce przewieziono wszystkich do Poznania, a stamtąd do Berlina. Na dworcu zakuto ich w kajdanki i prowadzono ulicami wśród umyślnie zebranych tłumów ludzi, którzy nie szczędzili obelg i szykan „polskim przestępcom”, jak ich nazywali. Po wyjeździe z Berlina przebywali jeszcze w kilku więzieniach. Podróż odbywała się etapami. Dłużej zatrzymali się tylko w Halle, gdzie zostali pobici przez naczelnika więzienia, a następnie - krócej już w Weimarze i Norymberdze, skąd trafili do Dachau ${ }^{30}$.

\subsection{Pobyt w obozie koncentracyjnym w Dachau}

Do Dachau ks. Henryk wraz z bp. Kozalem i grupą księży został przywieziony pociągiem 25 kwietnia 1941 roku. Cała podróż z Lądu do obozu trwała 3 tygodnie. W samym obozie przywitano jak ich jak w wielu innych miejscach, wypuszczono grupę wyrostków w wieku 18-20 lat, którzy bili bezlitośnie.

Oprawcy zmęczywszy się, odeszli, a nas poprowadzono do kancelarii obozu. Tu przechodziliśmy z izby do izby, z rąk do rąk urzędników i więźniów, poddając się różnym przymusowym obrzędom. Najpierw spisano nasze personalia, wpisano nas na listę więźniów i przydzielono każdemu obozowy numer. Następnie musieliśmy oddać ubranie, bieliznę, buty i wszystko, cokolwiek posiadaliśmy w rękach i na sobie, nawet krzyżyki i medaliki. Wszystko to pakowali więźniowie do worków i odnosili do przechowalni. Ostrzyżono nas i ogolono, po czym kazano nam przywdziać obozową bieliznę, pasiaki i trzewiki skórzane, które wkrótce mieliśmy zmienić na drewniane trepy. Tak przebrani, spoglądaliśmy 
nawzajem na siebie, a widok ten trochę nas śmieszył, bardziej bolał, ale każdy zachował się poważnie ${ }^{31}$.

W obozie nie było imion, zabierano je więźniom, tak jakby chciano pokazać, że z chwilą przekroczenia bramy zabiera się godność, tożsamość i historię, a nadaje numer, tak jakby człowiek stawał się przedmiotem z numerem ewidencyjnym, jak produkt na półce w sklepie. Naszemu błogosławionemu nadano numer 24547 i przydzielono go na czwartą izbę 28 baraku ${ }^{32}$. W każdym baraku był przełożony, tak zwany kapo, rekrutowany przeważnie spośród najbardziej zwyrodniałych więźniów kryminalistów czy komunistów, mógł on bezkarnie znęcać się nad więźniami w dowolny sposób, a nawet pozbawić ich życia. Kolejnym utrudnieniem był ciągły i niewyobrażalny głód. Ilość pożywienia była dokładnie wyliczona, tak aby waga więźnia po rocznym pobycie w obozie pozostawała w granicach $40-45 \mathrm{~kg}$. Często wymierzano kary za wszelkie przejawy modlitwy ${ }^{33}$.

Duchowni mieli pewne obozowe „przywileje”, które tak naprawdę były sposobem dręczenia ich. Przywilejem było „usługiwanie przy stołach" - polegało to na noszeniu 80-kilogramowych kotłów z jedzeniem na odległość nawet do 600 metrów. Księża musieli je nosić biegiem w niewygodnych i śliskich drewniakach pod groźbą kijów esesmańskich. Nie brakowało przypadków, gdy się przewracali, za co byli ciężko katowani. Zdarzało się, że przewracając się z kotłem, łamali nogi i ręce ${ }^{34}$. Nawet dwugodzinny odpoczynek stał się sposobnością do prześladowań. Dla przykładu pościelone łóżko musiało mieć kształt idealnego prostopadłościanu, w przeciwnym razie groziła kara słupka lub ciężkie pobicie. Nóż, widelec, menażka musiały lśnić czystością. Kontrole SS-manów były bardzo częste i zawsze im się coś nie podobało, najmniejsze niedociągnięcie mogło stać się przyczyną maltretowania ${ }^{35}$.

W tym obozowym piekle nigdy nie widziano ks. Henryka przygnębionego, czasem był smutny, miał przecież całe mnóstwo powodów ku

\footnotetext{
F. Korszyński, Jasne promienie w Dachau, dz. cyt., s. 31.

Por. S. Librowski, Ofiary zbrodni niemieckiej..., dz. cyt., s. 59.

33 Por. T. Kaczmarek, Nazizm hitlerowskijako „prześladowca wiary”, „Ateneum Kapłańskie”

34 F. Korszyński, Jasne promienie w Dachau, dz.cyt., s. 42.

35 Por. W. Frątczak, Biskup Michał Kozal..., dz. cyt., s. 154.
} 135 (2000), s. 29. 
temu. Ten smutek jednak był spokojny i miał w sobie coś, co innych krzepiło i podnosiło na duchu. Szykany najczęściej przyjmował z humorem religijnym $^{36}$ (tak to określa bp Korszyński), gdyż wszystko odnosił do Boga i Jemu wszystko składał w ofierze. Pewnie dlatego na jego twarzy tak często malowały się wielki spokój i pogoda ducha, a jego oczy tryskały życiem i radością.

Ksiądz Henryk nigdy nie należał do osób o mocnym zdrowiu, dlatego też na kilka tygodni przed śmiercią został przymusowo wcielony do tzw. grupy inwalidów. Na bloku inwalidów w pomieszczeniu 8 na 9 m leżało stłoczonych nawet 300 osób. Ich porcja żywieniowa była taka sama jak porcja zwykłego więźnia, dlatego przymierali głodem jak inni. Mimo to ks. Henryk, kiedy tylko miał okazję, dzielił się z księżmi normalnie pracującymi ${ }^{37}$. O tym, że ks. Henryk nie miał żadnych wątpliwości, co go czeka 6 maja, w dzień jego transportu, i że świadomie oddał swe życie Bogu, mówi świadectwo ks. Sarnika, świadka obozowych cierpień:

Oto pamiętny majowy dzień roku 1942. Na izbę wbiega jeden z naszych księży i woła: „Koledzy, chodźcie, popatrzcie, do inwalidów wjechało widmo!” Rzeczywiście stoi kryta, czarna ciężarówka. Wokół niej kręci się nerwowo obsługa bloku, ostre rozkazy dwóch esesmanów. Jeden z nich, z listą w ręku, wykrzykuje nazwiska. Niektórzy z wyczytanych już wychodzą. Naraz słyszę: „Kaczorowski Henryk!” Już go widzę. Wychodzi z izby, niezmiernie wychudzony, w obozowych pasiakach człowiek widmo. Szeroko otwartymi oczami rozejrzał się i spostrzegł mnie, stojącego za bramą.

Gdy esesmani byli czymś zaaferowani, podszedł ku mnie. Powiedział: „Władziu, powiedz wszystkim, aby się nie smucili. My się nie łudzimy. My wiemy, co nas czeka. Dominus regit me et nihil mihi deerit (Pan kieruje mną i niczego mi nie zabraknie). Przyjmujemy z rąk Bożych to, co nas czeka. Módlcie się za nas, byśmy wytrwali, a my również modlić się będziemy za was - tam”. I tu wskazał ręką ku niebu. Ostry świst esesmańskiego gwizdka przeszył powietrze. „Zostańcie z Bogiem!”38.

„Inwalidów” wywożono na zagazowanie do Harteim koło Linzu w Austrii. Potwierdzenie znajdujemy w raportach obozowych, których nie zdążono zniszczyć przed niespodziewanym wyzwoleniem obozu. Można w nich znaleźć

36 Por. W. Frątczak, Biskup Michał Kozal..., dz. cyt., s. 174.

37 Por. W. Frątczak, Biskup Michał Kozal..., dz. cyt., s. 172.

38 W. Sarnik, Ojczyzna męczenników zwycięża, „Ład Boży” 597 (1991), s. 8. 
krótką informację: czas konania wynosił ok. 6 min. ${ }^{39}$ Najprawdopodobniej w takich warunkach zginął ks. Henryk, choć akt zgonu wystawiony przez miejscowy urząd państwowy w Dachau podaję, że zgon nastąpił 21 czerwca o 16.30, a bezpośrednią przyczyną był udar mózgu. Wszelkie pewne informacje na temat naszego męczennika kończą się z odjazdem samochodu widmo. Nie znamy konkretnej daty śmierci, nie wiemy też na pewno, jak zginął, co czuł, jak się zachował, czy zdołał kogoś nawrócić, wyspowiadać, jak był tam traktowany. Kurtyna została zasłonięta.

\section{Kapłan ufający Bożej opatrzności}

Spośród wszystkich cnót, którymi odznaczał się bł. Henryk Kaczorowski, niezachwiana ufność w Bożą opatrzność wydaje się najbardziej charakterystyczna i najbardziej wybijająca w jego osobowości. Opatrzność Boża to zrządzenia, przez które Bóg prowadzi swoje stworzenie do ostatecznej doskonałości (por. KKK 302). Troska Opatrzności jest konkretna i bezpośrednia, obejmuje sobą wszystko, od rzeczy najmniejszych aż do wielkich wydarzeń świata i historii. Jezus domaga się dziecięcego zawierzenia Ojcu niebieskiemu, który troszczy się o najmniejsze potrzeby swoich dzieci. Jednak istnienie zła, niesprawiedliwości, grzechu, cierpienia mocno wystawia nasze zaufanie na próbę. Wspaniałymi przykładami są osoby doświadczone krzyżem, a mimo to mówiące: „Jezu, ufam Tobie”. Taką osobą był ks. Henryk, wierzył, że przez całe życie prowadzi go sam Bóg - Dobry Pasterz. Jemu należy zaufać i nie bać się stawiać czoła najtrudniejszym sytuacjom życiowym, gdyż są one z dopustu Bożego. Nie brakowało wręcz tragicznych sytuacji, ale ta głęboka ufność, że prowadzi go sam Bóg, a on jest Mu wierny, do końca dawała tę ogromną siłę do zmagania się z wszystkimi problemami.

Już od najmłodszych lat życie ciężko go doświadczało, jednak to tylko wzmacniało jego ufność w Bogu. Pierwszym znamiennym wydarzeniem, które musiało mocno wpłynąć na Henryka, była śmierć jego dwóch najmłodszych braci: Józefa i Jana. Każdy, kto stracił młodsze rodzeństwo,

39 Por. T. Kaczmarek, Błogosławiono ks. Henryk Kaczorowski, dz. cyt., s. 30-31. 
wie, co mógł czuć nasz błogosławiony. Nie wiemy, ile lat w chwili śmierci mieli jego bracia i sam Henryk. Wiemy natomiast, że byli siódmym i ósmym dzieckiem Andrzeja i Julii Kaczorowskich. A ponieważ Henryk był najstarszy, możemy przypuszczać, że miał około 10 lat ${ }^{40}$. Zapewne zapamiętał na całe życie widok słabnących braci, wysiłki rodziców, którzy starali się przywrócić zdrowie synom, ich łzy i płacz, aż wreszcie małe trumienki spuszczane w dół ziemi. Zapewne zapamiętał też księdza, który celebrował Eucharystię za jego braci i towarzyszył w ich ostatniej ziemskiej pielgrzymce. Takie chwile nie mogą nie prowadzić myśli do Boga. Może w sercu Henryka pojawił się żal, a może gorąca i ufna modlitwa o wieczny odpoczynek. Na pewno jest to bardzo trudne doświadczenie, które w sercu niejednego człowieka podważyłoby prawdę o dobroci Boga, ale nie w sercu naszego błogosławionego.

Życie nie rozpieszczało Henryka. W wieku 7 lat zamieszkał na stancji w Kłodawie $\mathrm{z}$ dala od rodziny ${ }^{41}$. W tak młodym wieku poradził sobie z rozłąką, wskazują na to chociażby bardzo dobre stopnie zdobywane w szkole i liczne pochwały nauczycieli ${ }^{42}$. Gdy trafił do Noskowa, musiał codziennie pokonywać 10 kilometrów pieszo do szkoły. Co prawda są to drobne krzyże, na pozór mogą się wydawać mało wartościowe. Lecz właśnie takie codzienne i wytrwałe znoszenie trudności wymaga wiele wysiłku. Świadczy to o jego wierze, że to, co go spotyka, nie jest przypadkiem. To wszystko dzieje się z dopustu Bożego i należy uczyć się wierności od samego początku w drobnych rzeczach (por. Łk 16, 10). Analizując dalszy życiorys naszego błogosławionego, można stwierdzić, że życie traktował jak zadanie dane przez Boga, które należy jak najlepiej wykonać, w tym zadaniu nie jest się samemu, zawsze towarzyszy nam Jezus. Jest wiele drobiazgów o tym świadczących, jak chociażby fakt, że pieniądze przeznaczone na drugie śniadanie przeznaczał na książki. Ogromna pilność

40 Por. ADWł, akta pers. ks. H. Kaczorowskiego, sygn.: pers 113, odpis listu brata księdza Kaczorowskiego z dnia 20 września 1946 r. zawierający informacje o nim. Jest to odpowiedź na zapytania stawiane przez księdza Librowskiego.

${ }^{41}$ Por. K. Rulka, Kaczorowski Henryk, w: Słownik polskich teologów katolickich, dz. cyt., s. 14.

42 Por. ADWł, akta pers. ks. H. Kaczorowskiego, sygn.: pers 113, odpis listu brata księdza Kaczorowskiego z dnia 20 września 1946 r. zawierający informacje o nim. Jest to odpowiedź na zapytania stawiane przez księdza Librowskiego. 
w nauce, zaciętość w czytaniu lektur, dbanie o wykształcenie młodszego rodzeństwa przejawiające się w nauczaniu historii i wydawanie domowego czasopisma. To wszystko znajduję potwierdzenie w słowach księży, którzy go znali, mianowicie to, że nie lubił próżności. Nieustannie pracował i tak spędzał czas, aby był z tego pożytek dla bliźniego, dla siebie i chwała dla Boga. Rezygnował od młodości z przyjemności tego świata, ofiarując swój czas, zainteresowania Bogu. Nie ma potrzeby powtarzać teraz ponownie całego życiorysu. Wzorowy alumn, pilny student, kochający syn, ofiarny kapelan, oddany duszpasterz, ascetyczny rektor. Skąd ta siła? Los co chwilę kierował go do nowych miejsc, nowych zadań, nowych ludzi. Mierzył się z wieloma problemami, śmiercią, wojną, przemocą, samotnością, biedą. Ileż razy musiał całkowicie zmieniać swoje życiowe plany. Głębię jego ufności najlepiej oddają zachowane świadectwa osób będących naocznymi świadkami heroicznej postawy, dlatego przyjrzyjmy się im, aby przekonać się o potędze tej cnoty w jego życiu. Na sam początek świadectwo bp. Franciszka Korszyńskiego, wieloletniego przyjaciela naszego błogosławionego:

Posiadał mocnego ducha, dzięki któremu pomimo wszystko miał zawsze wspaniałą postawę, promieniował na wszystkich i apostołował. Ta zaś postawa - to głęboka i żywa wiara, wprost dziecięca ufność, serdeczna, gorąca miłość Boga i bliźniego. [...] Ks. Henryk Kaczorowski od pierwszej chwili uwięzienia żył niezwykłą wiarą w Opatrzność i Jej rządy. Patrząc na wszystkie nawet na najokropniejsze przejawy niewoli przez pryzmat wiary, widział w nich dopust Boży i był przekonany, że wyjdą one na dobro poszczególnych jednostek, a zwłaszcza na dobro Kościoła i Polski. Stąd była w nim ta wprost imponująca równowaga ducha wśród największych szykan i ta niezwykła cierpliwość w znoszeniu utrapień ciała i ducha. Kto miał szczęście bliżej z nim współżyć, na pewno łatwo to zauważył, czasem nawet był zdumiony, a chyba zawsze takim przykładem był pokrzepiony, podniesiony na duchu ${ }^{43}$.

Ten kapłan wyczerpany pracą, prześladowaniem wroga, a zwłaszcza zniszczony okropnym głodem i wyglądający nad wiek starczo, był niezwykle silnego ducha, bo niezwykła była jego ufność w opiekę i pomoc Bożą. Jakby hasłem jego obozowego życia stały się słowa Psalmisty: „Dominus regit me, et nihil mihi deerit” (Ps 23, 1). Te słowa często miał w myśli i na ustach; z nich czerpał siłę, która pogłębiała w nim, wzmacniała i ożywiała i takjuż wielką ufność w pomoc Bożą. [...] Powiedzieć trzeba także, iż ks. Henryk Kaczorowski, jako teolog żyjący wiarą, umiał wmyślić się w ekonomię Bożą. Jest ona wprawdzie nieskończona, dla słabego umysłu ludzkie-

43 F. Korszyński, Jasne promienie w Dachau, dz.cyt., s. 170. 


\section{Jakub Wiśniewski}

go niepojęta, ale jeśli człowiek patrzy na nią okiem wiary, wsparty wiedzą teologiczną, może przynajmniej do pewnego stopnia odgadywać jej cele, plany i drogi. Tak właśnie czynił ks. Kaczorowski i dlatego lepiej niż wielu innych rozumiał kataklizmy i klęski, jakie przeżywała ludzkość ostatnich czasów, a zwłaszcza dopusty Boże w stosunku do Polski i Kościoła. Dlatego też pojmował sens naszego pobytu w Dachau. Jego zdaniem posłał nas tam Pan Bóg w takiej masie po to, byśmy byli żertwą Bożą, hostią, ofiarą, która miała przyczynić się do przejednania gniewu Bożego i do przygotowania lepszej przyszłości całej ludzkości, a w szczególności Kościołowi ${ }^{44}$.

Drugim naocznym świadkiem jest bp Kazimierz Majdański, który w czasie obozowej niedoli był jeszcze klerykiem. Tak opisuje swojego byłego Rektora:

Osobowość promieniująca zawsze - w czasach spokojnych, wśród klęsk największych i na dnie obozowej nędzy - spokojem, opanowaniem, „zwyczajnością” postawy. Charakter jak monolit. [...] Nigdy nie narzekał, nigdy nie wypowiedział słowa skargi i żalu, spokojnie przyjmował wszystko, co przyszło tak nieoczekiwanie i torturowało tak okrutnie. [...] To wszystko cicho i cierpliwie. - Kryterium niezawodne prawdy o dojrzałym człowieczeństwie i o dojrzałym kapłaństwie, wyraz heroicznego męstwa chrześcijańskiego, które nie krzyczy buńczucznie, bo umie znacznie więcej: umie nieść krzyż, wpatrzone w Cichego Baranka. [...] Do końca zachował równowagę, a nawet pogodę. Do końca autentyczny. Do końca nie był zdziwiony niczym. Zdaniem naszym były to znamiona heroizmu ${ }^{45}$.

\section{Podsumowanie}

Nie ma wątpliwości co do tego, że ks. Henryk całkowicie ufał Bożej opatrzności. Każdy etap swojego życia odczytywał jako plan Boży. Głęboko wierzył, że zawsze jest przy nim Bóg, który go wspiera. Wyjątkowym sprawdzianem były czasy obozowe, sprawdzianem, który zdał celująco. Wielkość cnoty ukazują zwłaszcza trudne sytuację. Nie sztuka ufać, kiedy się dobrze wiedzie i nie ma większych problemów w życiu. Sztuką jest zachować ufność w sytuacji, kiedy trzeba oddać życie. Cnota jest darem Bożym, a człowiek jest wezwany, aby tę cnotę przyjąć i przez całe życie nad nią pracować.

44 F. Korszyński, Jasne promienie w Dachau, dz.cyt., s. 171, 174.

45 K. Majdański, Ks. Henryk Kaczorowski, „Ateneum Kapłańskie” 86 (1976), s. 406-407, 410. 


\section{Summary}

\section{Opatrzność Boża w życiu błogosławionego Henryka Kaczorowskiego}

Powyższy artykuł ukazuje bł. ks. Henryka Kaczorowskiego jako kapłana ufającego opatrzności Bożej.Jego życie pełne było trudnych doświadczeń, które tylko wzmacniały jego wiarę i ufność. Najtrudniejszym sprawdzianem był czas II wojny światowej, a zwłaszcza pobyt w obozie koncentracyjnym w Dachau, skąd został wywieziony do Harteim, gdzie najprawdopodobniej został zagazowany.

Jest to wspaniały przykład człowieka, który w każdym doświadczeniu, nawet tym najtrudniejszym, doszukuje się zamysłu Bożego. Dlatego też w każdej okoliczności należy wykazać się postawą pełną ufności. Zwłaszcza księża, którzy borykają się $\mathrm{z}$ wieloma problemami, mogą wiele się nauczyć od bł. ks. Henryka, szczególnie że nie ma tak trudnej sytuacji z którą dzięki Bogu nie można sobie poradzić.

Słowa kluczowe: ufność, opatrzność Boża, ks. Henryk Kaczorowski, obóz koncentracyjny

\section{Trust in Divine Providence in the Life of the Blessed Priest Henryk Kaczorowski}

The blessed priest Henryk Kaczorowski is shown as a priest trusting in Divine Providence in the above article. His life abounded with difficult experiences which strengthened his faith and trustfulness. The toughest test of his faith took place during the World War II, especially during his imprisonment in the Dachau concentration camp from where he was deported and probably gassed in Harteim.

His life serves as a prime example of a man who tried to find Divine Providence in every single experience, regardless of how difficult it is. Thus, one should adopt a trusting approach under any circumstances. Especially priests facing numerous problems have much to learn from the blessed priest Kaczorowski, as there exists no situation with which one could not cope with God's help.

Keywords: trust, Divine Providence, blessed priest Henryk Kaczorowski, concentration camp

\section{Bibliografia}

Archiwum Diecezji Włocławskiej, akta pers. Ks. H. Kaczorowskiego, syng.: pers 113, odpis listu brata księdza Kaczorowskiego z dnia 20 września 1946 r. zawierający informacje o nim. Jest to odpowiedź na pytania zadawane przez księdza Librowskiego. 


\section{Jakub Wiśniewski}

Biblioteka Wyższego Seminarium Duchownego, Błogosławiony ks. Henryk Kaczorowski. Zaświadczenie lekarskie o stanie zdrowia z 17 VIII 1940.

Dajczer T., Rozważania o wierze, Częstochowa 2012.

Frątczak W., Biskup Michał Kozal. Życie - męczeństwo - kult, Włocławek 2009.

Gogola J. W., Mistycy i mistyka Karmelu, Kraków 2007.

Jacewicz W., Woś J., Martyrologium polskiego duchowieństwa rzymskokatolickiego pod okupacją hitlerowska w latach 1939-1945, Warszawa 1977, t. 1, s. 82-88.

Jan Paweł II, Encyklika Fides et ratio (14 IX 1998), „Acta Apostolicae Sedis” 91 (1999), s. $5-88$.

Kaczmarek T., Błogosławiony ks. Henryk Kaczorowski, Włocławek 2001.

Kaczmarek T., Nazizm hitlerowski jako „prześladowca wiary”, „Ateneum Kapłańskie” 135 (2000), s. 29-43.

Kaczmarek T, Świadkowie wiary, Włocławek 2013.

Korszyński F., Jasne promienie w Dachau, Poznań 1957.

Librowski S., Ofiary zbrodni niemieckiej spośród duchowieństwa diecezji włocławskiej 1939-1945, Włocławek 1947.

Majdański K., Bądźcie moimi świadkami, Łomianki 1999.

Majdański K., Ks. Henryk Kaczorowski, „Ateneum Kapłańskie” 86 (1976), s. 404-410.

Olejnik S., Takie to były czasy, tacy to byli ludzie. Karty dziennika, Wrocław 2009.

Poniński A., Kaczorowski Henryk, w: Włocławski Słownik Biograficzny, Włocławek 2002

Rulka K., Kaczorowski Henryk, w: Słownik polskich teologów katolickich, pod red L. Grzebienia, t. 6, Warszawa 1981-

Ryken L., Wilhoit J. C., Stownik symboliki biblijnej, tł. W. Chrostowski, Warszawa 2003.

Sarnik W., Ojczyzna męczenników zwycięża, „Ład Boży” 597 (1991), s. 8.

Szymański J., Ksiądz Henryk Kaczorowski: moralista, rektor $i$ wychowawca, „Studia Włocławskie" 11 (2009), s. 431-440. 